\title{
CHANGES IN THE CHEMICAL COMPOSITION OF GROUNDWATER IN QUATERNARY AQUIFER IN OLD KRAKOW, POLAND (YEARS 2002-2012)
}

\author{
Agata KASPRZAK, Jacek MOTYKA \& Marta WARDAS-LASOŃ \\ AGH University of Science and Technology, Faculty of Geology, Geophysics \\ and Environment Protection; al. Mickiewicza 30, 30-059 Krakow, Poland; \\ e-mail: agata.kasprzak@gmail.com
}

\begin{abstract}
The chemical composition of the Quaternary aquifer in Old Krakow was studied. Thirty water samples were collected from wells in the years 2002, 2009 and 2012. The water chemistry of groundwater in Old Krakow is associated mainly with anthropogenic impact. The water samples represent manly five-ion type: $\mathrm{Ca}-\mathrm{Na}-\mathrm{Cl}-\mathrm{HCO}_{3}-\mathrm{SO}_{4}, \mathrm{Ca}-\mathrm{Na}-\mathrm{Cl}-\mathrm{SO}_{4}-\mathrm{HCO}_{3}$ and $\mathrm{Ca}-\mathrm{Na}-\mathrm{HCO}_{3}-\mathrm{SO}_{4}-\mathrm{Cl}$, the multi-ion water type is typical for polluted water. The results of groundwater studies in Krakow between 2002 and 2012 showed that the chemical composition of water is being constantly affected by ancient human activities. The predominance of chloride and nitrate ions can be connected with a large number of the contamination sources. The main sources of contamination are accumulations of the anthropogenic soils and the cultural deposits containing organic, communal waste and sewage which were gathered in the oldest parts of Krakow.
\end{abstract}

Key words: urban hydrogeology, Krakow, chemical composition, anthropogenic factors, pollution

\section{INTRODUCTION}

The complicated geological structure within Old Krakow is connected with the presence of numerous horsts and grabens. It contributes to the changes in groundwater flow (Kleczkowski 2003). Both this and anthropogenic processes have an important impact on the chemical composition of groundwater. The changes in the Quaternary aquifer chemistry were caused by centuries-old activities of the people living in the agglomeration - mainly by sewage poured out into the streets, leachate from municipal landfills, and also activities of craftsmen and trade (Motyka et al. 2012). This can be seen in a mosaic arrangement of concentrations of individual components in relatively small areas. Regardless of the efforts to improve water quality and an increasing environmental awareness of the Old Krakow inhabitants, negative changes in groundwater chemistry have been observed in the last decade. High-density housing results in reduced direct infiltration within the city centre, increased surface runoff and lower evaporation. Therefore, the reduction in groundwater recharge for Quaternary aquifer results in extended time of water self-cleaning. 
The main objective of this paper is the description of changes in chemical composition of Quaternary aquifer in the Old Krakow area over the last decade, and also the presentation of urban impact on the groundwater quality.

\section{METHODS}

Thirty water samples were collected from Quaternary wells in the years 2002, 2009 and 2012. The sampling places are presented in the Figure 1.

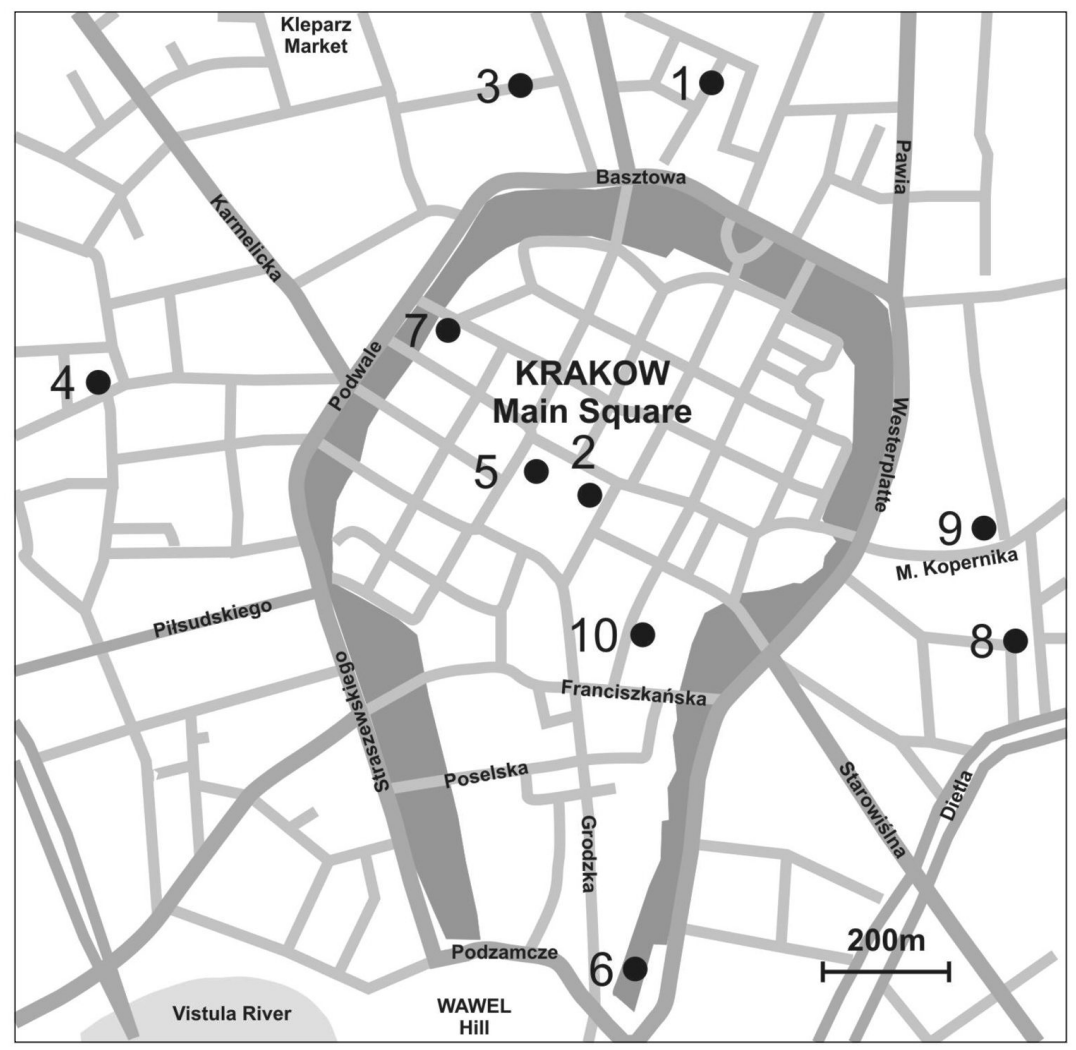

Fig. 1. Location of sampling points (1-10)

The $\mathrm{pH}$, conductivity and temperature were measured in the field. The total dissolved solids (TDS) were calculated by summing the concentrations of the major ions. Chloride (Cl) concentrations were determined by the Mohr's method, using 0.01 molar $\mathrm{AgNO}_{3}$. Concentration of nitrates $\left(\mathrm{NO}_{3}\right)$ was determined using the capillary electrophoresis method with Perkin-Elmer 270 AH-T. The total alkalinity (as bicarbonate $\mathrm{HCO}_{3}$ ) was determined using 
0.05 molar $\mathrm{HCl}$ acid by Gran titration. The concentration of other components was determined by inductively coupled Optical Emission Spectrometry (ICP OES) using a Perkin-Elmer OPTIMA 7300DV. All laboratory analyses were conducted in the Hydrochemical Laboratory of the Department of Hydrogeology and Engineering Geology, AGH the University of Science and Technology in Krakow.

\section{STUDY AREA}

Complicated geological structure is characteristic for the Krakow area. This region is situated at the borders of large tectonic units: the Silesian-Krakow Monocline, Miechów Synclinorium and Carpathian Foredeep. Numerous, small tectonic horsts and grabens were formed during the Alpine movements. Horsts are composed of Oxfordian limestones, which are surrounded by Miocene clay and Quaternary deposits filling neighboring grabens (Rutkowski 1994).

The Krakow area is built from Jurassic, Cretaceous, Tertiary and Quaternary deposits, creating four aquifers (Kleczkowski et al. 1994). The Jurassic aquifer is represented mainly by Oxfordian limestones, which are full of karst cavities and conduits. Because of numerous faults, these deposits have an important impact on the groundwater flow. Due to this the water level is stabilized at various depths.

The Cretaceous aquifer consists of cracked Senonian deposits (marls and gaizes), and also Cenomanian and Turonian arenaceous and organogenic limestones with conglomerates (Rutkowski 1989). These sediments are covered by the Jurassic deposits filling the tectonic grabens. On the ground surface the presence of Cretaceous forms is infrequent.

The Tertiary aquifer connected with the Miocene sands is significant locally. In some places in karst sinkholes are filled by Paleogene limestones and marl debris. Mineral water was formerly extracted for medical purposes from drills e.g. near Mateczny roundabout.

The Quaternary aquifer consists of fluvial sands and gravels, sediments reach the maximum thickness of 10-15 m (Kleczkowski 1989). The deposits are partially overlaid by anthropogenic soils, accumulated with centuries of human activity (Fig. 2).

The Krakow area is drained by the Vistula River and recharged in two different ways, namely by lateral inflow of the surface water from the Vistula valley, as well as by infiltration of precipitation (Zuber et al. 2004). Predominantly, the groundwater level is unconfined, only in grabens, where the Jurassic and Cretaceous sediments are covered by the Miocene clays, confined or even artesian water occurs. Due to this fact, the groundwater was divided into the local and the regional hydrodynamic and, at the same time also hydrogeochemical water circulation zones. In the upper part of the sediments, water stays for relatively short time interval (a few decades), while in the lower layers, the time is much longer, reaching hundreds or even thousands years. Because of vertical zones of faulting within the Old Krakow area, the foregoing aquifers are in hydraulic contact, which influences the groundwater chemical composition. 


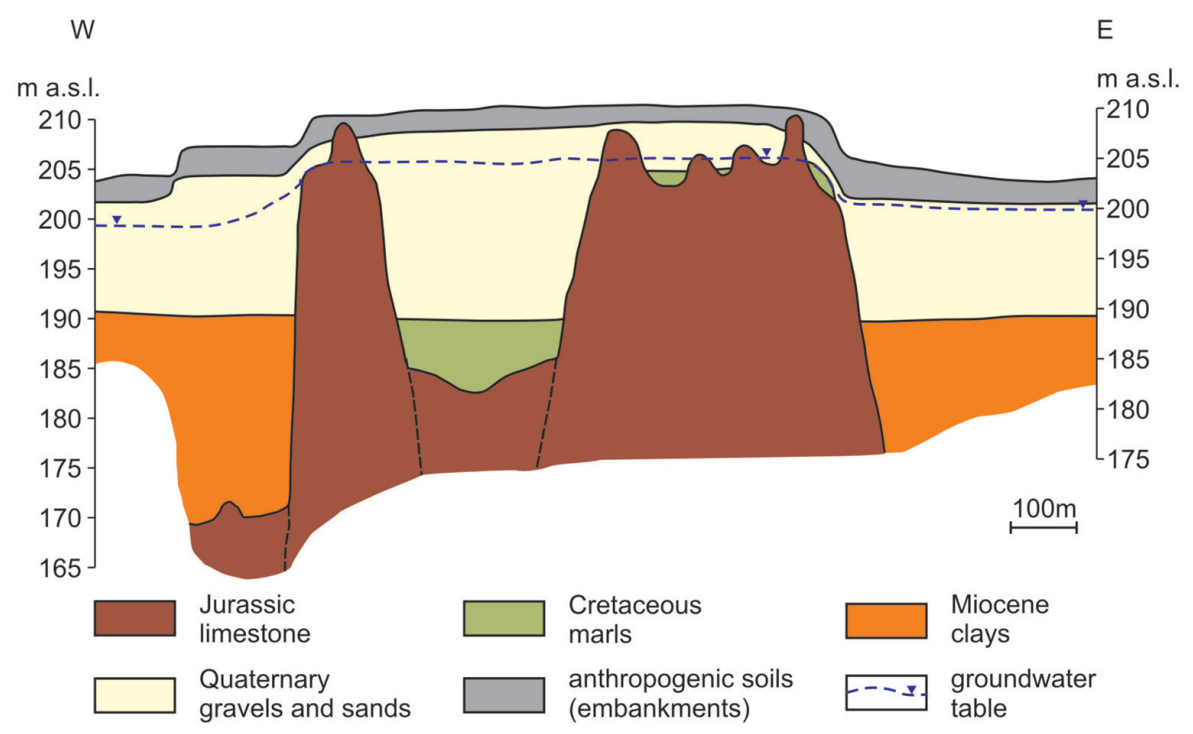

Fig. 2. Hydrogeologic schematic cross-section of Krakow Old City (Kleczkowski 2003)

\section{RESULTS}

The study of the chemical composition of Quaternary aquifer in Old Krakow was analyzed between 2002 and 2012. These studies showed significant changes in the concentrations of the individual components in a relatively small area. Also, changes in the chemical composition of the individual sampling points were observed each year. Total dissolved solids (TDS) of the samples vary greatly and range from $489 \mathrm{mg} / \mathrm{L}$ to $5000 \mathrm{mg} / \mathrm{L}$, but in 2002 they ranged from $489 \mathrm{mg} / \mathrm{L}$ to $2073 \mathrm{mg} / \mathrm{L}$. In 2009 - from $603 \mathrm{mg} / \mathrm{L}$ to $5006 \mathrm{mg} / \mathrm{L}$ and finally in 2012 - from $916 \mathrm{mg} / \mathrm{L}$ to $2443 \mathrm{mg} / \mathrm{L}$. Generally, as the years passed, minimal TDS increase in individual wells was observed, only in well No. 2, 5, 9 value decreased (Tab. 1).

Among the main cations, sodium and calcium are dominant in the water samples. Calcium concentrations range from $66 \mathrm{mg} / \mathrm{L}$ to $670 \mathrm{mg} / \mathrm{L}$ (with the highest values recorded in the well No. 10 at Gertrudy Street), while sodium levels vary from $31 \mathrm{mg} / \mathrm{L}$ to $456 \mathrm{mg} / \mathrm{L}$. Only one sample from well No. 5, located on the Main Square, has higher concentrations of sodium ions - above $1700 \mathrm{mg} / \mathrm{L}$.

Chloride and bicarbonates dominated amongst anions. Chloride concentrations ranged from $24 \mathrm{mg} / \mathrm{L}$ to $696 \mathrm{mg} / \mathrm{L}$, except the well No. 5 where the maximum value was $2800 \mathrm{mg} / \mathrm{L}$. Bicarbonates varied from $100 \mathrm{mg} / \mathrm{L}$ to $987 \mathrm{mg} / \mathrm{L}$. Also, in the case of the above mentioned components the uptrend of concentrations was observed. The concentrations of $\mathrm{NO}_{3}$ (measured only in year 2012) vary from less than $0.5 \mathrm{mg} / \mathrm{L}$ to $61.66 \mathrm{mg} / \mathrm{L}$, highest concentration was found in the Main Square sampling point (measured in year 2009 and 2012). 
궁ำ

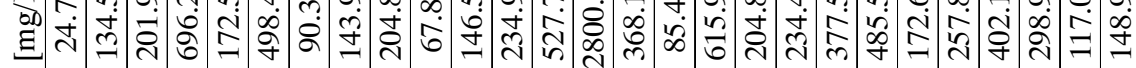

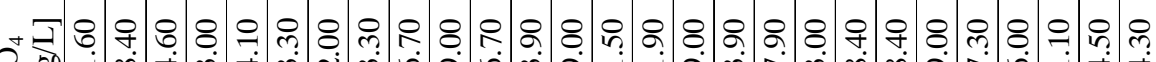

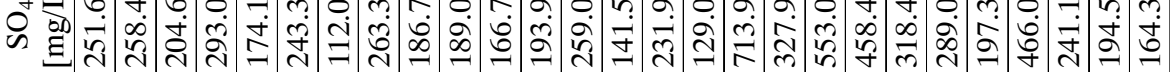

피 ㅇํ กิ

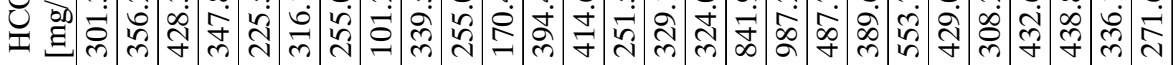

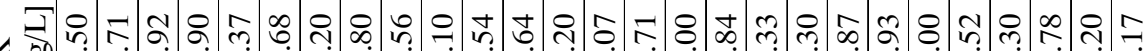

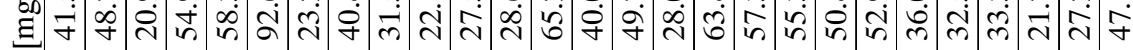

๘

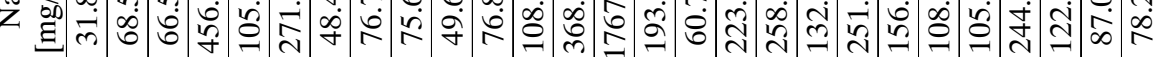

我雪 छ

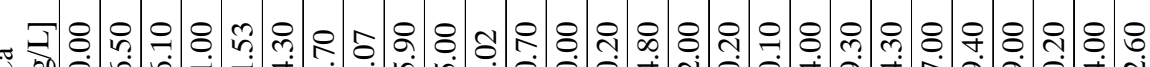
J

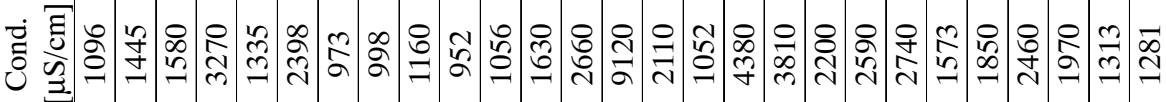

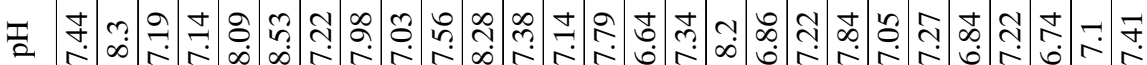

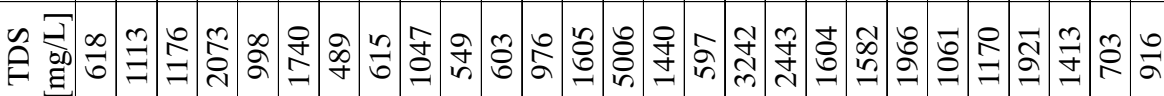
مَّ 离

\begin{tabular}{|c|c|c|c|c|c|c|c|c|c|c|}
\hline$\frac{\ddot{d}}{\frac{\pi}{2}}$ & 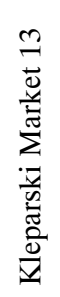 & 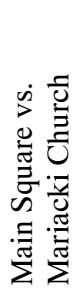 & 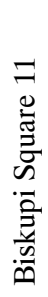 & 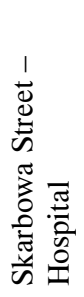 & 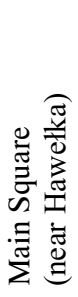 & 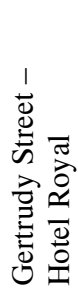 & 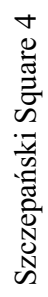 & 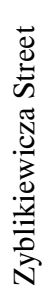 & 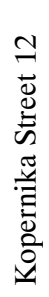 & 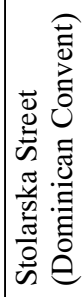 \\
\hline$\dot{z}$ & $\neg$ & $N$ & $m$ & $\nabla$ & $n$ & 0 & $r$ & $\infty$ & $a$ & $=$ \\
\hline
\end{tabular}




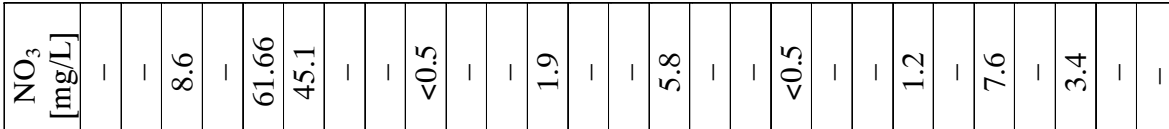

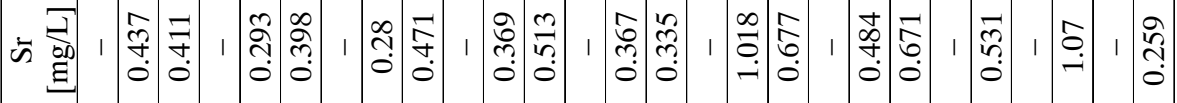

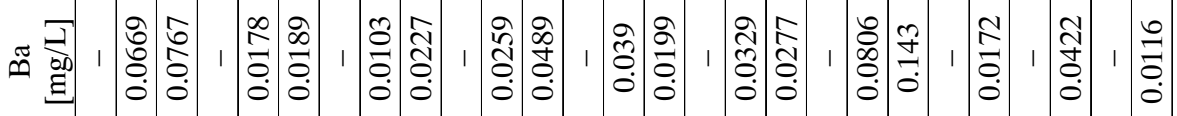

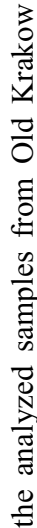

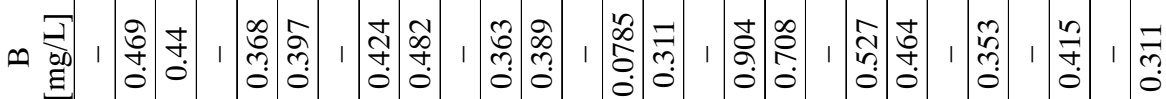

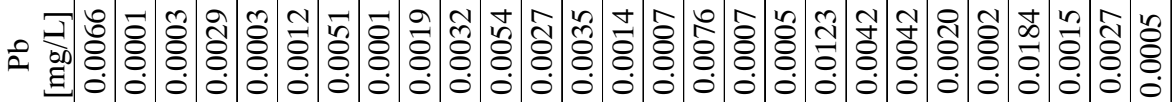

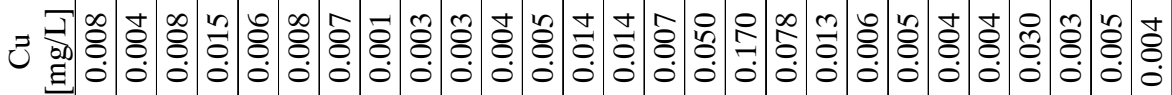

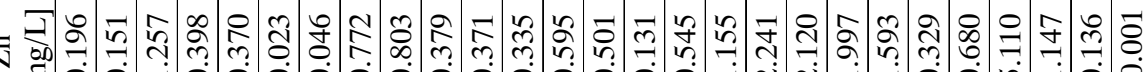
当

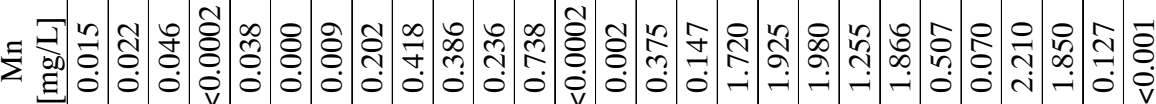

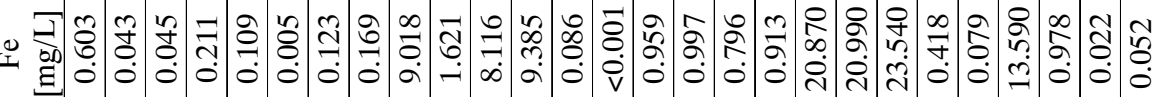

ڤึ

\begin{tabular}{|c|c|c|c|c|c|c|c|c|c|c|}
\hline$\frac{\ddot{E}}{\tilde{\alpha}}$ & 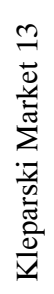 & 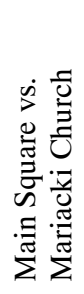 & 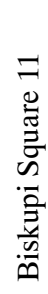 & 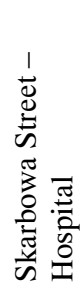 & 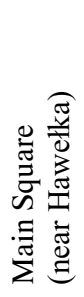 & 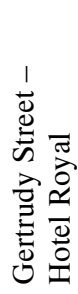 & 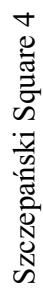 & 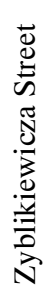 & 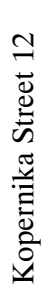 & 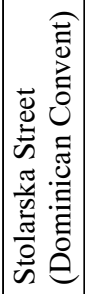 \\
\hline$\stackrel{\dot{Z}}{\mathbf{z}}$ & $\neg$ & $N$ & $n$ & $\nabla$ & in & 6 & $r$ & $\infty$ & $a$ & \\
\hline
\end{tabular}


Iron and manganese are dominated microelements in the studied samples. Fe concentrations in the water samples range between less than $0.001 \mathrm{mg} / \mathrm{L}$ and $23.54 \mathrm{mg} / \mathrm{L}$, with the highest values noticed in the Szczepański Square well. Mn value ranges from $0.0002 \mathrm{mg} / \mathrm{L}$ to $2.2 \mathrm{mg} / \mathrm{L}$. Generally these microelements exceed the Polish limit for drinking-water quality. Apart from $\mathrm{Fe}$ and $\mathrm{Mn}$ the studied samples contain significant amounts of $\mathrm{B}, \mathrm{Sr}, \mathrm{Ba}$ and $\mathrm{Zn}$. Some samples contain small amounts of $\mathrm{Cu}$ and $\mathrm{Pb}$ (Tab. 2).

\section{DISCUSSION}

The Quaternary aquifer in the Krakow area is formed by sands containing calcium carbonate, therefore natural water should belong to $\mathrm{Ca}-\mathrm{HCO}_{3}$ type. However, centuries of history have had a significant impact on changes in the groundwater quality (Kleczkowiski et. al. 2009).

The research results of the main components concentrations in the Quaternary waters allowed separating fourteen water types. Most common are five-ion: $\mathrm{Ca}-\mathrm{Na}-\mathrm{Cl}-\mathrm{HCO}_{3}-\mathrm{SO}_{4}$, $\mathrm{Ca}-\mathrm{Na}-\mathrm{Cl}-\mathrm{SO}_{4}-\mathrm{HCO}_{3}$ and $\mathrm{Ca}-\mathrm{Na}-\mathrm{HCO}_{3}-\mathrm{SO}_{4}-\mathrm{Cl}$ compositions (Fig. 3). The multi-ion type is typical for polluted water. Only in the water from the well No. 2 near Mariacki Church, $\mathrm{Na}-\mathrm{Ca}-\mathrm{Cl}$ type was observed twice. Water sampling in year 2009 from well No. 5, which shows the highest levels of mineralization, also belongs to a different hydrogeochemical type, namely Na-Cl. Taking this fact into account, as well as the date of taking this sample (April 2009) and its generally high mineralization, the authors suppose that during the winter, when the plate of the Main Square was treated with salt against any ice layer, some salt penetrated inside the well; especially that the water samples taken from the same well tested in 2002 and 2012 are characterized by significantly lower general mineralization and multiion hydrogeochemical type.

Nitrate concentrations in groundwater range from $0 \mathrm{mg} / \mathrm{L}$ to $8 \mathrm{mg} / \mathrm{L}$. These values are relatively low, but high nitrate concentration was observed in the Main Square in the Mariacki Church vicinity and its average value is $50 \mathrm{mg} / \mathrm{L}$. It is likely that the groundwater pollution by nitrates in the city centre was caused by the flower trade, which takes place in this area. Grischek et al. (1996) came to the similar conclusion in their research.

Fluctuations in the concentration of iron, manganese and zinc are determined by redox potential; therefore identification of the causes of these fluctuations is relatively difficult and requires additional research.

A clear rise of chlorides, sulphates and potassium can be observed in the tested water samples, which can result from water contamination by leachates from municipal waste and sewage, which, for many years, were simply thrown out into the streets. The results presented, where an uptrend can be observed in these components concentration within the last decade, testify to a continuing influence of anthropopression on the water chemistry. 


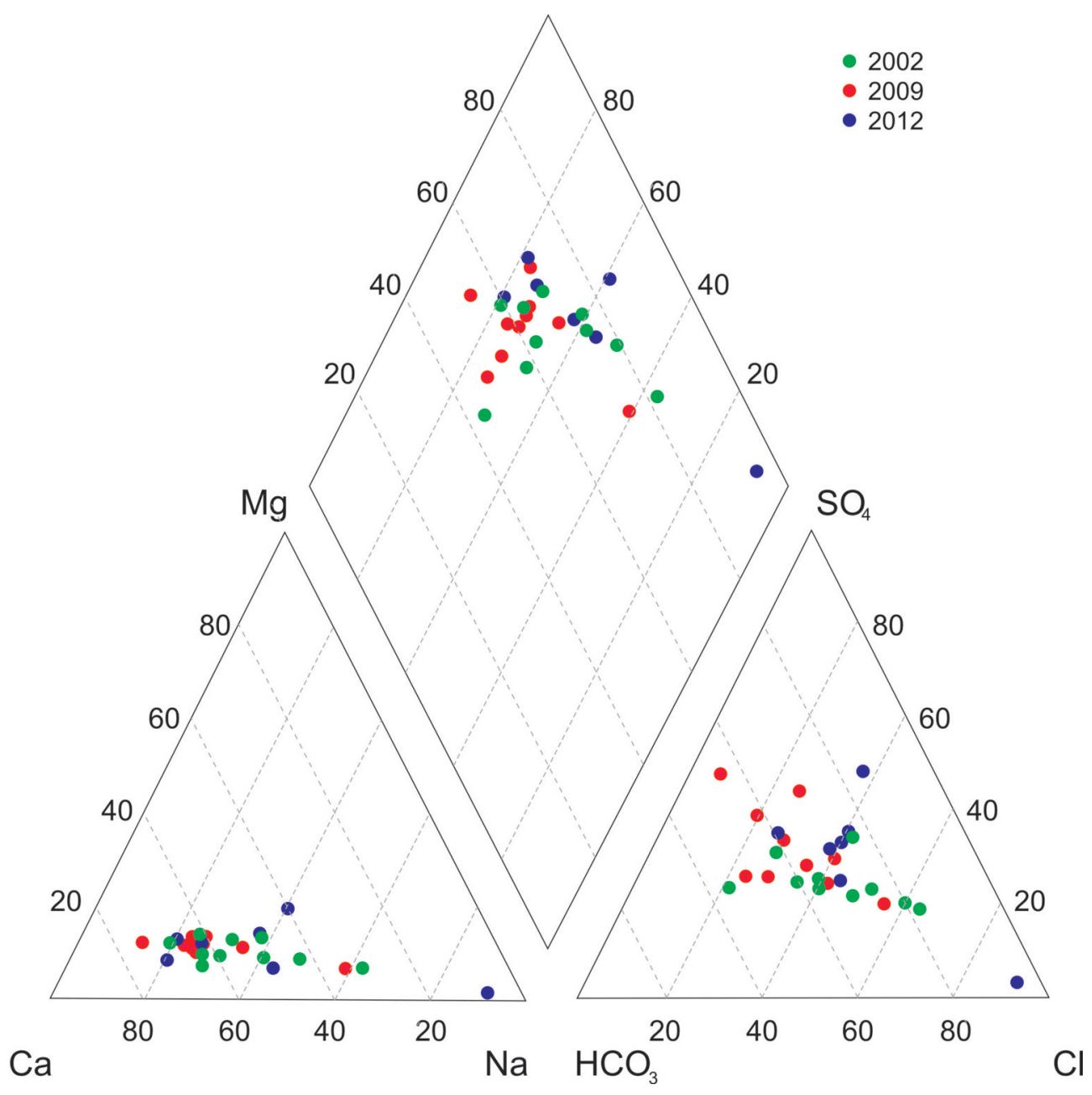

Fig. 3. Piper diagram showing the ionic composition of studied samples from Old Krakow

Diverse chemical composition of groundwater in a relatively small area suggests that Quaternary aquifer is affected by various sources. Concentrations of individual components arranged in a specific mosaic pattern suggest the presence of many points releasing pollution, such as the disposal and storage of waste, sewage, the waste connected with crafts and trade, etc. (Fig. 4).

Not only anthropopression, but also geogenic factors has an influence on the chemical composition of groundwater. 

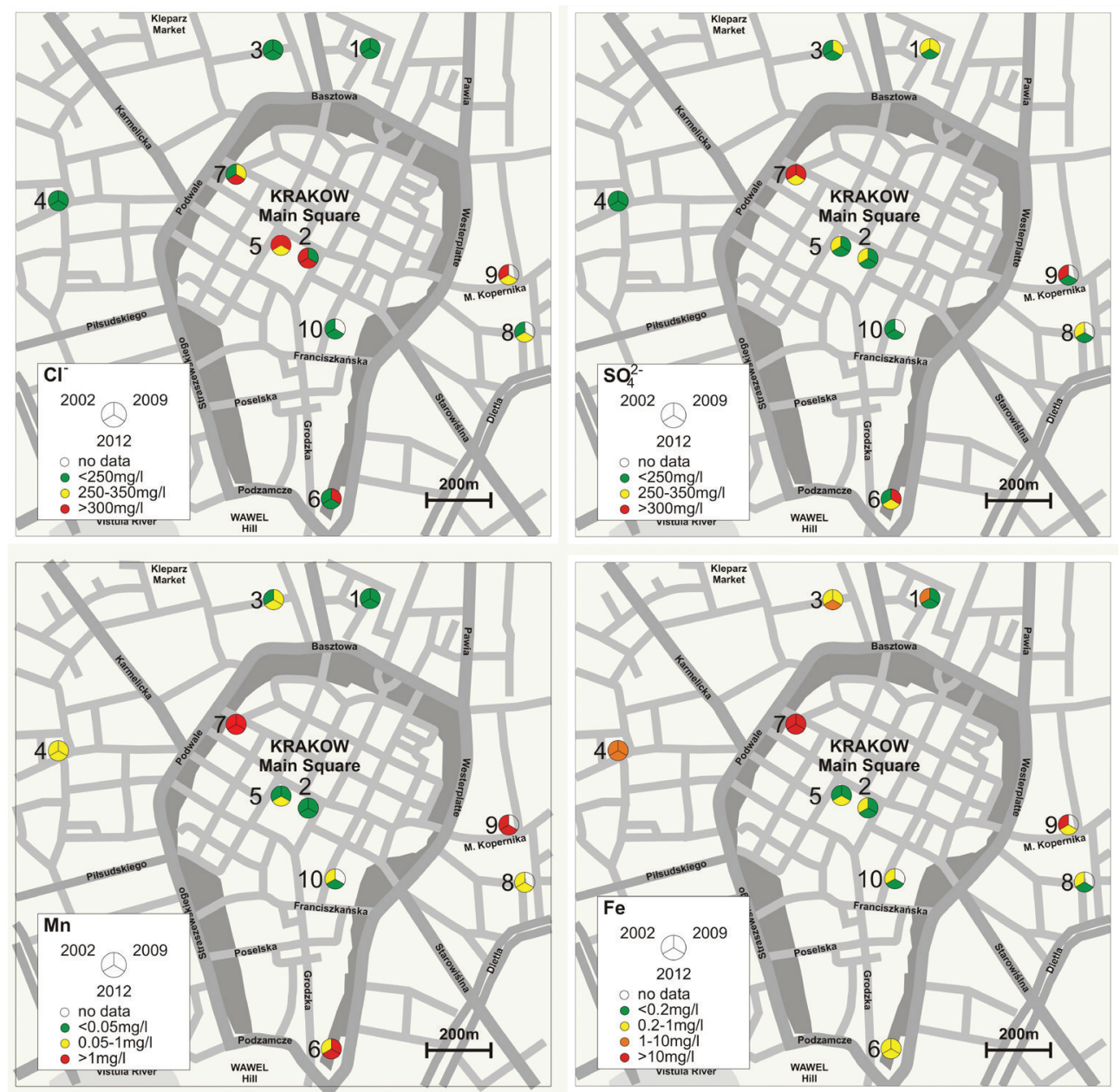

Fig. 4. Concentrations of selected components in sampling points in year 2002, 2009 and 2012

\section{CONCLUSIONS}

Both the geogenic and anthropogenic factors affect the chemical composition of shallow groundwater in the Old Krakow area. Due to calcium carbonate occurring in Quaternary sands and the surrounding Jurassic limestone, calcium and bicarbonate should dominate in this water. Moreover, numerous horsts and grabens can make the upflow of mineralized water from the deeper aquifer possible, which can lead to heightened chloride concentrations (Kleczkowski 2003). But, taking into consideration the multi-ion water type results from most of the samples, the conclusion is that strong anthropopression has a major impact 
on the groundwater quality. The extreme variation of concentrations of each macro- and microelements in a relatively small area, indicate the existence of a large number of point pollution sources. In many sampling points there is a possibility to observe an upgoing trend of concentrations of ions, such as: $\mathrm{Cl}, \mathrm{Ca}, \mathrm{Fe}$, and $\mathrm{Zn}$ in the last decade. In some places the chemical composition of groundwater is changing in every sampling year. This indicates a continuous impact of the past and present history of Krakow on the water quality. We should note that in an urban area, where direct infiltration and evaporation is reduced, the extension of time of self-purification of Quaternary groundwater is observed.

\section{REFERENCES}

Grischek T., Nestler W., Piechniczek D. \& Fischer T., 1996. Urban groundwater in Dresden, Germany. Hydrogeology Journal, 4, 1, 48-63.

Kleczkowski A.S., 1989. Szkic zagadnień hydrogeologicznych Krakowa. Przeglad Geologiczny, 6, 323-326.

Kleczkowski A.S., 2003. Ksztattowanie chemizmu czwartorzędowych wód podziemnych Krakowa 1870-2002; tendencje dalszych zmian. Wydział Geologii, Geofizyki i Ochrony Środowiska AGH, Kraków.

Kleczkowski A.S., Myszka J., Solecki T. \& Stopa J., 1994. Krakowskie artezyjskie zdroje wód pitnych w wapieni. Wydział Geologii, Geofizyki i Ochrony Środowiska AGH, Kraków.

Kleczkowski A.S., Czop M., Motyka J. \& Rajchel L.Z., 2009. Wpływ czynników geogenicznych i antropogenicznych na skład chemiczny wód podziemnych w Krakowie. Geologia [AGH UST quarterly], 35, 1, 117-129.

Motyka J., Wardas-Lasoń M., Czop M. \& Kasprzak A., 2012 Chemizm wód podziemnych w rejonie Rynku Głównego w Krakowie w świetle nowych danych. [in:] Nawarstwienia historyczne miast: forum naukowe 2008, Wydawnictwa AGH, Kraków, 311-330.

Rutkowski J., 1989. Budowa geologiczna rejonu Krakowa. Przeglad Geologiczny, 6, 302308.

Rutkowski J., 1994. Introduction to the geological structure of the Cracow region. Third International Meeting of Peri-Tethyan Epicratonic Basins (IGCP 343), Excursion Guidebook, Polish Geological Institute, Warszawa.

Zuber A., Weise S.M., Motyka J., Osenbruck K. \& Różański K., 2004. Age and flow pattern of groundwater in a Jurassic limestone aquifer and related Tertiary sands derived from combined isotope, noble gas and chemical data. Journal of Hydrology, 286, 87-112. 